\title{
APP-067-AMアンチアンドロゲン交替療法における，セカンドライン・フルタミドの臨床的有用性とそ の予測ノモグラムの作成・検証
}

\author{
千葉大学大学院医学研究院泌尿器科学1), NASA-PC 研究会 ${ }^{21}$, 京都府立医科大学泌尿器科学 ${ }^{31}$

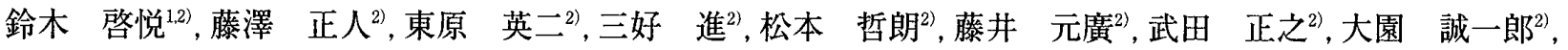 \\ 碓井 亞 ${ }^{2}$, 松田 公志 ${ }^{2}$, 公文 裕已 ${ }^{2)}$, 市川 智彦 ${ }^{12}$, 三木 恒治 ${ }^{2,3}$
}

【目的再㷦前立腺癌に対する治潦戦略は，完全に確立されたものはない。MSKCCの Kellyらが提唱した再燃前立腺癌のモデルによれば，前立腺癌の木ルモン 環境からみた進行はるつのクライテリアに分類される。初回木ルモン療法再然の段階では,「アンドロゲン非依存性ホルモン感受性癌】である可能性が高く，こ の場合には、アンチアンドロゲン除去症候群 (AWS) の有無の確認・アンチアンドロゲン交替療法が推奖される。一方, 价ンドロゲン非依存性ホルモン非感受 性癌】では早期の化学療法導入が推奖される。今回, 非ステロイド性アンチアンドロゲン交替療法の症例を対象に效果予測ノモグラムの作成を行なったので報

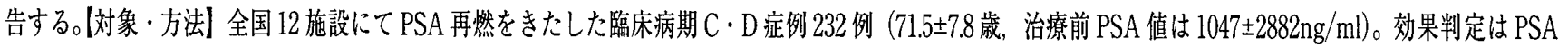
の変動に基づき，有効期間はPSAの再上昇までとした。全例で莧物的もしくは外科的去勢を併用した。このうちビカルタミドからフルタミドへの交替症例は 193 例であり，この群についてさらに解析を進めた。結果じカルタミドでの1次 MAB 療法に対しては 74\%でCRを $26 \%$ でPRを得た。PSA50\%以上低下し

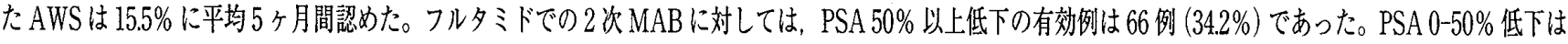
51 例 (26.4\%) に認められ、合計 60.6\%でPSA の低下を観察した。PSA が50\%以上低下した場合だけでなく 0-50\%低下した群も，初回治療開始から癌死・ 初回再然から癌死ともに，長期的に良好な予後が認められ，『アンドロゲン非依存性ホルモン感受性癌】゙あると考えられた。逆に，七カンドライン・アンチア

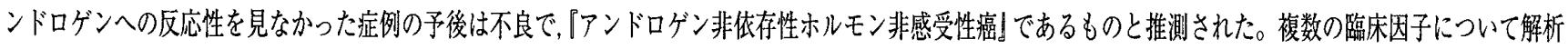
し, 治療前 PSA 值・1 次 MAB 療法での PSA nadir 值・儖床病期・Gleason score を用いてセカンドライン・フルタミドの反応性 (PSA 低下 $50 \%$ 以上) と不応 性(PSA 低下なし)を予測する2つのノモグラムを作成した。さらに他施設からのデータセットを用いて external validationをおこなったところ，ROC曲線の AUCが 0.800 と優れた感度・特異度を有することが検証された。考察]再燃前立腺癌の治潦戦略において，アンチアンドロゲン交替潦法の有用性は既にエビデ ンスとして確立されつつある。再燃前立腺癌に高龄者や広笽な骨転移を有する患者が多いことを考えると，アンチアンドロゲン交替療法梳初回木ルモン療法再 然後の治㙩戦略として非常に有望なものと考えられる。今回作成されたノモグラムを使用することで, アンチアンドロゲン交替療法の効果から，癌の「ホルモ ン感受性】の有無が予測可能となり，ドセタキセルを主体とした化学療法の導入時期などを患者ごとの個別化 (オーダーメイド化)できるものと考兄ら机た。

\section{APP-068-AM ステージC 前立腺癌における待機的照射療法の検討〜ネオアジュバンドで PSA が充分に 下降した場合に照射を見合わせることは可能か〜}

\section{新潟県立がんセンター新潟病院泌尿器科}

斎藤 俊弘, 若月 俊二, 北村 康男, 小松原 秀一

【目的】ステージ C 前立腺癌の標準治療の第一選択は「放射線＋内分泌治療」とされるが、「分泌単独療法」でも良好な経過をとる症例 は多く存在する。それではまず内分泌治療を行い、その反応性をみてから放射線治療の追加を検討するという「(内分泌療法を行った上 での) 待機的照射療法」というストラテジーは成立しうるのか検討する。【方法】 1992 年〜2005 年に当科で治療したステージC 前立腺癌 298 例のうち、内分泌単独療法もしくは内分泌+照射で治療されていた 272 例（平均年齢 74.4 歳、平均 PSA $59.2 \mathrm{ng} / \mathrm{ml}$ 、平均観察期間 62.7 ヶ月）を対象とし、retrospective に以下のような検討を行った。1）内分泌療法の初期反応性について内分泌治療 6 ケ月後のPSA 值を指標として検討し、反応性良好の群と不良の群に分けて「内分泌単独療法群」と「内分泌+照射群」の治療成績を比較した。2)(意 図するしないにかかわらず）内分泌療法で下降したPSAが再上昇を認めた時点になってから前立腺部に照射を加えた症例（待機照射 群）の治療成績を検討した。成績】 1) 内分泌治療 6 ヶ月後の PSA が $1 \mathrm{ng} / \mathrm{ml}$ 末満となっていた症例と $1 \mathrm{ng} / \mathrm{ml}$ 以上であった症例では疾 患特異的 5,10 年生存率がそれぞれ $95.4 \% ， 90.2 \%$ および $86.9 \% ， 34.0 \%$ であり、治療成績に有意差がみられた。6 ケ後のPSA が 1 $\mathrm{ng} / \mathrm{ml}$ 以上の症例では「内分泌単独群」と「内分泌＋照射群」の疾患特異的 5,10 年生存率がそれぞれ $80.2 \%, 24.5 \%$ および $97.0 \%, 48.5 \%$ で有意差があったが $1 \mathrm{ng} / \mathrm{ml}$ 末満となっていた症例はいずれの治療群も成績良好 (疾患特異的 5,10 年生存率がそれぞれ $93.5 \%, 87.2 \%$ および 96.9\%，92.0\%）で有意差が見られなかった。2）内分泌療法で下降したPSAが再上昇を認めた時点になってから照射を加えた 14 例 (待機照射群)の疾患特異的 5 年生存率は $100 \%$ であり、nadiar 時点もしくはそれ以前に照射を行った症例と遜色なかった。結論】 結論：内分泌療法6ヶ月の時点での PSA 值が良好な場合、疾患特異的生存は治療法のいかんにかかわらずおおおね良好であり、内分泌 療法の初期反応性をみてから照射の追加の必要性を決めるという方針はあり得ると考えられた。また、PSAが上昇に転じた時点で直ち に照射を加えた症例と、nadiar 時点もしくはそれ以前に照射を行った症例の治療成績に明らかな差がなかったことより、内分泌療法の 初期反応性が良好ならば内分泌単独療法で治療開始し、その後のサルベージ療法の第 1 選択として直ちに照射を行う「(内分泌療法を 行った上での）待機的照射療法」という戦略もステージC 前立腺癌の一つの治療選択肢となりうると思われた。 